\title{
The Effectiveness of Technology Innovation In Tax Payment Services on Compliance of Land and Building Tax
}

\author{
Temy Selafristy ${ }^{1}$, Abdul Rahman ${ }^{2}$ \\ Politeknik STIA LAN Bandung, Jl. Cimandiri 34-38 Bandung 40115 ${ }^{12}$
}

\{abdul.rahman@poltek.stialanbandung.ac.id² ${ }^{2}$ \}

\begin{abstract}
The current technological development is increasingly being felt and even adopted by the society. Certainly, people are starting to be friendly with technology because of a positive effect in providing various conveniences for the society. One of them is the ease to do financial transactions anytime and anywhere, as the impact of the presence of Financial Technology in Indonesia. By this reason, the government also take the advantages of financial technology in paying taxes, especially Land and Building Tax. Likewise, the presence of financial technology is able as a basis for the payment service innovations in both the government and private sectors. This study aims to determine the effectiveness of technological innovation in tax payments on land and building tax payment compliance. The research method used is quantitative research using survey techniques to find out public opinion about the topic raised. The results of the study show that technological innovation in the payment of Land and Building Tax is proven to be effective in influencing taxpayer compliance, using 5 indicators, namely timeliness, accuracy of amounts, absence of arrears, availability to give information for the officers, and awareness to pay taxes.
\end{abstract}

Keywords: technological innovation; financial technology; taxpayer; regional government; land and building tax

\section{Introduction}

The development of technology is a development that cannot be avoided over time. This is undeniable as it has been proven that technology can bring tremendous benefits to the global community. The development of technology is increasingly noticeable today in all areas. Almost all forms of work directly or indirectly use technological progress, which is of course supported by increasingly qualified human resources in order to create technological innovations such as financial technology or so-called financial technology (FinTech).

Financial technology is one of the types of technologies that is currently being actively developed. The development of FinTech has made it possible to guarantee the population the convenience of processing financial transactions anytime and anywhere. FinTech can be the driving force behind many types of innovation used by both the government and the private sector in the provision of payment services. According to the definition of the National Digital Research Center (NDRC), Aliyudin [1] stated that financial technology, or more commonly known as FinTech, is the term used to describe innovation in financial services, the term being 
derived from the words "' financially "and" financially". Technology "which refers to financial innovations with a touch of modern technology.

The convenience that financial technology offers can make that technology one of the goals of technological innovation aimed at making it easier to access people. Likewise, during this period, the government began adopting technology to provide services to the public. As with the payment of taxes, especially the property and building tax (PBB). According to Tuwo [2], the land and building tax (PBB) is a tax levied on the land that includes land, inland waterways and seas within the territory of the Republic of Indonesia and / or buildings, including engineering works, that are on land located and or water.

The management of PBB P2 was transferred from the central government to the local authorities after the adoption of Law No. 28 of 2009, with the aim that the land and building tax revenues can be fully used directly to accelerate the development of the area [3 ]. However, the vastness of the regions in Indonesia is often an obstacle for PBB management, as there is still potential that does not yet need to be realized.

The same thing happened in the Bogor Regency. For this reason, a team for Regional Tax Implementation Technique (UPT) has been formed under the auspices of the Regional Revenue Management Agency (Bappenda) so that regional tax revenues, especially property and building taxes, can be properly implemented, resulting in optimal performance and achievement of gates. The Regional Tax UPT, in accordance with Regent Ordinance No. 103 of 2011, is intended to provide information on taxes.

Traditionally, tax payments have traditionally been made when the taxpayer had to go to the identified competent government agencies or regional banks. But today, thanks to technological innovation, tax payments can be made anywhere, anytime. Currently, using financial technology as a means of payment, payments can be made through certain government-designated applications or websites.

The incentive of the local government to socialize the land and building tax, accompanied by technological innovations in payment, made it possible to increase the implementation of the land and building tax of the Bogor reign. The reign of Bappenda Bogor stated that the realization of land and building tax receipts as of August 31, 2020 was IDR 438,081,380,322, or 107.90\%, more than IDR 32,082,594,322 from the target of 405,998,786,000 previously set in the third quarter

Technological innovations in property tax and building tax have been introduced throughout most of Indonesia. As in the city of Semarang, Murbasari [4] found in his study that a partnership between the local government and PT Gojek Indonesia, which uses Gopay as a financial technology as a PBB payment innovation, creates a reciprocal relationship as it could increase regional income. and increase public confidence in the Gojek app.

In addition, Sari [5] in his study in Mojokerto Regency showed that the level of use of public technologies for making PBB payments, especially through banking services, is still quite low and requires socialization. Unlike the city of Solo. Ardianti [6] found in its study that the use of the regional tax office Solo, known as (EPPSON), improved the quality of services and made it easier for taxpayers to pay taxes.

It is expected that technological innovations in tax services will improve taxpayers' compliance with taxes, especially property and building taxes, so that regional property and building tax revenues can be optimized. Therefore, this study was carried out to find out how effective tax innovations are in influencing taxpayers' compliance with property taxes.

\section{Literature Review}




\section{Efficiency}

According to Windiarty and Sofian [7], efficiency is the use of resources, space and infrastructure in a certain amount, which is deliberately specified in advance for the production of a series of goods for the services provided. Effectiveness means whether a given goal has been achieved. The more the goal or objective is achieved, the higher the efficiency.

\section{Land and Building Tax}

According to Law No. 28 of 2007, the tax is a compulsory contribution to the state due to a natural or legal person, which is compulsory under the law, without direct compensation and is paid for the needs of the. uses the state for the highest good of the people. ... In addition, Law No. 28 of 2009 on regional taxes and regional fees stipulates that regional taxes, hereinafter referred to as taxes, are "compulsory payments to the regions due to natural or legal persons who are entitled under the law, without receiving benefits in kind, directly and used for regional needs for the highest good of the people. "

One of the taxes examined is the property and building tax (PBB). According to Ordinance No. 13 of 2011 on Taxes on Rural and Urban Land and Buildings, rural and urban land and building taxes are "taxes on land and / or buildings owned by natural or legal persons, that of natural or legal entities covering the rural sector and urban areas, with the exception of land used for plantations, forestry and mining. "

According to Anarogi [8], land and buildings provide benefits and / or better socioeconomic conditions to those entitled to them, and therefore it goes without saying that the government requires the government to provide some of the benefits or pleasures that the state imposes on them Receives expenses from taxes. From this we can conclude that the real estate and building tax is the implementation of the tax collection on land that consists of land, land and buildings that are used for personal or business interests.

a. Subject of the property and building tax

According to Article 77 of Law No. 28 of 2009 on Regional Taxes and Regional Fees, land and building taxable objects in rural and urban areas are land and / or buildings owned, controlled and / or used by individuals or organizations with Except for the area used for plantation cultivation, forestry and mining.

b. Collection bases, tariffs and calculation methods for property taxes in rural and urban areas as well as for building projects

The basis for the introduction of PBB P-2 is the sales value of the taxable item or NJOP. Base and Building Tax Rates (PBB Bogor Regency): a) NJOP below or above Rs $1,000,000,000$ set at $0.11 \%$; b) NJOP over Rs $1,000,000,000$ is set at $0.22 \%$. The NJOPTKP amount is INR $10,000,000$ (ten million rupees). Meanwhile, the NJKP is between $20 \%$ and $40 \%$ of the NJOP. Main method PBB P2 $=\operatorname{tariff} x$ (NJOP - NJOPTKP)

\section{Innovations}

According to Law No. 18 of 2002, innovation is defined as research, development and / or engineering activities aimed at the practical application of new scientific values and contexts or new ways of applying existing scientific and technological advances in products or manufacturing to develop . Process. In addition, Elitan and Anathan [9] found that innovation is a change in an organization that involves creativity in creating new products, services, ideas or new processes. Innovation is also widespread in the public sector. Anaroga [8] also found that there are typologies of innovation in the public sector, namely product or service innovation, process innovation, service innovation, strategy or policy innovation, and systemic innovation.

In this study, innovation used by the government is a method of innovation in service 
methods. The government is innovating by using financial technology to provide the PBB with alternative payment services. Innovations in tax payment are realized by providing various services that allow the population to pay taxes anytime, anywhere. Of course, innovation in tax payment is related to the financial technology or fintech that is currently developing. Land and building tax innovations that the community can take advantage of today include banking, ecommerce applications, the Regional Financial Management Agency's official website, and payments through Indomaret and Alfamart merchants.

\section{Financial Technologies (FinTech)}

According to OJK [1], financial technology, also known as FinTech, is an activity that integrates business processes, business models and financial instruments that create new added value for the financial services sector by incorporating the digital ecosystem. In addition, according to Bank Indonesia, FinTech is the result of a combination of financial services and technology that could finally change the business model from traditional to modern, which is initially a personal payment and transports a certain amount of cash in seconds.

The availability of financial technology makes the buying, selling and payment transactions more efficient and effective. The FinTech benefits that enable efficient and effective performance can be a tool for governments to innovate by providing alternative tax options, particularly property and building taxes. Having FinTech is a means of paying taxes through certain apps or websites.

\section{Taxpayers' compliance}

The Agency for Financial Education and Training of the Ministry of Finance of the Republic of Indonesia declares that taxpayers' compliance with tax obligations is the fulfillment of tax obligations that taxpayers fulfill in order to contribute to continuous development, which is to be done on a voluntary basis. In addition, compliance with the requirements set by Norman D. Novak [2] by the taxpayer is explained as follows. 1) understand taxpayers or try to fully and clearly understand all the provisions of the legislation; 2) fill out the tax form completely and clearly; 3 ) correctly calculate the amount of tax payable; 4) Pay the tax due on time.

\section{Research Methods}

The method used in this study is a quantitative method with survey methods. The data in this study was obtained from the local municipality of the Bogor reign of about 50 people who have paid taxes on land and construction, both women and men in various occupations. The data was collected through the distribution of online questionnaires through the Google Form application. Statements in the questionnaire on certain research variables.

\subsection{Study variable}

This indicator of compliance with property and building taxes is a modification of the study by Yusnidar et al. [10], which is explained as follows. 1) Taxpayers always pay taxes on time; 2) Taxpayers always pay the correct amount of tax; 3) taxpayers have no debt; 4) Taxpayers provide tax information whenever officials need it; and 5) taxpayers believe that, as decent citizens, it is necessary to take steps to meet their tax obligations.

\subsection{Data collection and analysis phases}

The steps to collect and analyze data are described below. 
a. Distribution of questionnaires. This questionnaire contains 5 statements on research indicators. The measuring scale used in this study is the Likert scale. This Likert scale is a series of declarative statements given to respondents to indicate their level of agreement so that they disagree with the statements in the study. The Likert scale used in this study is a scale with a scale range from 1 to 5 , as follows: 1) Score $1=$ totally disagree; 2) Grade 2 = do not agree; 3 ) Grade 3 = neutral; 4) grade 4 = agree; 5) Grade 5 = totally agree

b. Data table. Give respondents' answers a value based on pre-defined intervals. When creating the tables, the respondents' answers are summarized in a table that is then used as analysis material.

c. Data analysis. After the questionnaire data had been summarized, the data was processed using the MS Excel software. The analysis of the data aims to determine the effectiveness of innovations in the payment of property and building taxes based on the percentage compliance indicators by taxpayers.

d. Application of data. After analyzing the data, it can be presented in the form of tables and interpretations showing the effectiveness of technological innovations in paying land and building taxes.

\section{Result and Discussion}

Land and Building Tax is one of the local government revenues originating from tax objects in the form of buildings that are owned, controlled, and utilized by both individuals and entities. The effectiveness of technological innovation in PBB payments is expected to have a good influence on taxpayer compliance.

Based on the survey conducted, data were obtained from 50 PBB taxpayers domiciled in Bogor Regency. The identity of the respondents can be explained in table 1 below.

Table 1. Identity and Payment method of Land and Building Tax in Bogor Regency

\begin{tabular}{|c|l|c|c|}
\hline No & \multicolumn{1}{|c|}{ Information } & Number & $\begin{array}{c}\text { Percentage } \\
(\mathbf{\%})\end{array}$ \\
\hline A & Occupation & & \\
\hline 1 & Apparatus/State Enterprises/Army/Police & 4 & 8 \\
\hline 2 & entrepreneur & 6 & 12 \\
\hline 3 & Private sector employee & 15 & 30 \\
\hline 4 & Student & 15 & 30 \\
\hline 5 & Teacher & 2 & 4 \\
\hline 6 & Housewife & 8 & 16 \\
\hline B & Payment method of Land and Building Tax & 13 & 26 \\
\hline 1 & Bank transfer (ATM, Mobile Banking) & 16 & 32 \\
\hline 2 & Applications (Tokopedia, Gopay, Shopee, at) & 2 & 4 \\
\hline 3 & Alfamart and Indomaret outlets & 2 & 4 \\
\hline 4 & Local Government Site & 17 & 34 \\
\hline 5 & Regional Bank/Post Office/Local Village & & \\
\hline
\end{tabular}

Source: Survey, 2021

Based on table 1, the results show that the majority of respondents have switched to using financial technology in paying the Land and Building Tax. This is evidenced by the 
conventional payment method chosen by only $34 \%$ or 17 of 50 respondents. Then, regarding the effectiveness of tax payment innovations, the survey results were obtained which can be explained in table 2 below:

Table 2. The results of the survey on the effectiveness of technological innovation in the payment of Land and Building Tax on Taxpayer compliance

\begin{tabular}{|c|l|c|c|c|c|c|}
\hline No & \multicolumn{1}{|c|}{ Indicator } & \multicolumn{5}{c|}{ Percentage (\%) } \\
\cline { 3 - 7 } & & $\begin{array}{c}\text { Very } \\
\text { Disagree }\end{array}$ & Disagree & Neutral & Agree & $\begin{array}{c}\text { Very } \\
\text { Agree }\end{array}$ \\
\hline 1 & Taxpayers always pay taxes on time & 0 & 0 & 8 & 32 & 60 \\
\hline 2 & $\begin{array}{l}\text { Taxpayers always pay taxes in the } \\
\text { correct amount. }\end{array}$ & 0 & 0 & 0 & 32 & 68 \\
\hline 3 & Taxpayers have no debt & 0 & 2 & 28 & 46 & 24 \\
\hline 4 & $\begin{array}{l}\text { Taxpayers believe that, as decent } \\
\text { citizens, it is necessary to take steps } \\
\text { to meet tax obligations. }\end{array}$ & 0 & 6 & 26 & 48 & 20 \\
\hline 5 & $\begin{array}{l}\text { Taxpayers always provide tax } \\
\text { information when an employee } \\
\text { needs it }\end{array}$ & 0 & 0 & 6 & 30 & 64 \\
\hline
\end{tabular}

Source: Survey, 2021

\subsection{Taxpayers always pay taxes on time}

According to the survey, $60 \%$ of respondents totally agree, 32 agree and $8 \%$ expressed doubts that technological innovations in tax payment could enable taxpayers to pay PBB on time. This shows that technological innovations in tax payment are effective in improving taxpayers' compliance, particularly in terms of timeliness. PBB payment services that have started implementing technology have proven that they can get taxpayers to pay PBB on time. Of course, this can happen because technology enables taxpayers to pay taxes anytime, anywhere. The availability of technology can eliminate the reasons why taxpayers, especially workers, make their limited time an obstacle to paying taxes on time. Today's tax innovations are easy to use, so that even active taxpayers no longer have any barriers to making PBB payments.

\subsection{Taxpayers always pay taxes in the correct amount}

According to the results of the survey on the topicality indicators, $68 \%$ of respondents totally agree and $32 \%$ agree. When it comes to the effectiveness of technological innovations on this indicator, the respondents fully agree. This shows that the presence of technological innovation in PBB payments is effectively influencing taxpayers to pay the correct amount. The technology used for tax payments can provide accurate billing information to $\mathrm{PBB}$ prior to the due date. This can make it easier for taxpayers to prepare funds for PBB payments so that payments can be made at the invoice rate. Therefore, it is imperative to invite people who have no underpayment or even excess taxes due to the wrong denomination.

\subsection{Taxpayers have no debt}

Based on a study on the effectiveness of innovative payment technologies without tax arrears for taxpayers, $24 \%$ of the respondents totally agree, $46 \%$ agree, $28 \%$ doubt and $2 \%$ disagree. This shows that the presence of technological innovation in PBB payments does not fully affect taxpayer's compliance, especially with regards to the zero debt ratio. The availability 
of technology in the provision of payment services has not been able to optimally influence the taxpayer so that he can regularly pay land and building taxes and thus have no debts. While technology can make it easier to make payments through the PBB anytime, anywhere, when it comes to late payments through the $\mathrm{PBB}$, it is still up to the taxpayer to meet their tax obligations.

\subsection{Taxpayers believe that, as decent citizens, action is required to meet their tax obligations}

In the survey, $20 \%$ of the respondents fully agree, $48 \%$ agree, $26 \%$ express doubts and $6 \%$ of the respondents disagree that technological innovations sensitize taxpayers when paying PBB. This shows that technological innovation in property and building taxes has not fully contributed to raising taxpayers' awareness of the need to make payments through the PBB. Some recent apps may already have features that might remind taxpayers 'awareness, but this does not fully raise taxpayers' awareness, especially those who make payments using other financial technologies. Awareness of the payment of land and building taxes may still not depend on the simplicity of the payment process alone but depends on each taxpayer.

\subsection{Taxpayers provide tax information whenever officials need it}

According to the survey, $66 \%$ of respondents totally agree, $30 \%$ agree and $6 \%$ have doubts that payments with technological innovations can force taxpayers to provide the information required by the tax authorities. Technological innovation in services is a form of cooperation between the state and the private sector, in particular FinTech as a tax payment service provider, which is also registered with the Financial Services Authority (OJK). Of course, thanks to the partnership with this tax payment service provider, the private sector has been given permission to participate in the issuing of valid and accountable evidence of tax payments to the tax inspector. This can certainly increase public confidence in making PBB payments through other parties in collaboration with the government.

\section{Conclusion and Recommendation}

The land and building tax is a form of compulsory community tax for the ownership or use of land and buildings in a region. Therefore, almost all buildings or land in Indonesia are taxed in blood by $\mathrm{PBB}$, so every person, family or organization has to pay $\mathrm{PBB}$. The presence of technological innovations in PBB payments is expected to be very effective in terms of taxpayer compliance.

This study was conducted in the Bogor Regency with 50 respondents who are PBB taxpayers. The survey results show that the majority (over 50\%) of respondents have switched to using technology when making payments through $\mathrm{PBB}$, rather than making payments in the traditional way or in person with local institutions. The presence of technological innovations in tax payment services, particularly property and building taxes, has been shown to be effective in influencing tax compliance in payments. While there are indicators that don't show such a high percentage, they nonetheless show that technological innovations in PBB payments are effective, if not entirely, affecting taxpayers' compliance.

This study shows that the rate of effectiveness of technological innovation in paying PBB is highest in terms of numerical accuracy in the survey results: $68 \%$ of respondents totally agree and $32 \%$ agree. In addition, the taxpayer awareness indicator was found to be the least efficient in the survey results: $20 \%$ of respondents totally agree, $48 \%$ agree, $26 \%$ express doubts and $6 \%$ disagree. 
Based on the study, the authors propose suggestions for further socialization related to technological innovations in the payment of land and building taxes. Survey results show that $34 \%$ still use regular direct payments. However, in the context of Indonesia during this pandemic, it is not advisable to make regular payments as this will of course trigger community movements that will allow the spread of Covid-19. Hence, it is hoped that the community can better benefit from the services of the local government. This study focuses exclusively on the effectiveness of PBB's innovative payment technologies, which are currently providing greater convenience. Due to the limitations of this study, in the future, the study about the effectiveness of technological innovations related to tax services toward the compliance of payment of Land and Building Tax .

\section{References}

[1] Aliyudin, R.S.: The Role of Fintech in Increasing Tax Revenues in Indonesia. J-Action, 1 (1), 56-67 (2020)

[2] Tuvo, V .: Impact of Taxpayer Attitude and Awareness on Compliance with Land and Construction Tax Regulations in Tara-Tara Village, Tomohon City. EMBA Journal: Journal of Economic Research, Management, Business and Accounting, 4 (1) (2016)

[3] Erwin: Optimizing Rural and Urban Land and Building Tax Revenues (Pbb P2) at Upt Pd Parung Bappenda Bogor Regency. Unpak Professional Magazine (2020)

[4] Mubasari, RA, and Martini, R .: Partnership between Semarang City Government and PT. Gojek Indonesia as a Go-Pay service provider for land and construction taxes in Semarang City. Journal of Political and Government Research, 10 (2), 54-66 (2021)

[5] Sari, SDE: Efforts to Increase Land and Building Taxes Through Banking Institutions in the Regency of Mojokerto. Doctoral dissertation, Muhammadiyah Malang University (2020)

[6] Ardianti, OT: Analyzing Innovation in Local Tax Services with EPPSON (Electronic Regional Tax Application) in Surakarta. Journal of Political and Government Research, 9 (04), 346 - 358 (2020)

[7] Vindiarty, V. and Sofian, M .: Analysis of the Efficiency of Tax Revenue from Land and Construction in Depok. Ekbank Scientific Journal, 1 (2) (2018)

[8] Anoraga, A .: Innovation in Land and Building Tax Services (PBB) through the Drive Thru Program (research at the Banyuwangi Tax Office). University of Bravijaya (2014)

[9] Agustia I. and Sadad A. Innovation in e-Billing at Pekanbaru Tax Office Tampan Pratama. Riau University (2017)

[10] Kharlina, V.I .: Factors Affecting Taxpayers' Compliance with Land and Construction Taxes in Rural and Urban Areas. Drive Thru Program of the University of Muhammadia in Yogyakarta (training at the Banyuwangi Tax Office). University of Bravijaya (2016)Gantino, R. (2016). Pengaruh corporate social responsibility terhadap kinerja keuangan perusahaan manufaktur yang terdaftar di bursa efek Indonesia periode 2008-2014. Jurnal Dinamika Akuntansi Dan Bisnis, 3(2), 19-32.

[11] Setiawan, T., \& Purwanti, A. (2017). Piramida Carroll Pada Perusahaaan di Indonesia: Studi Pada 3 Perusahaan Pemenang Csr Award 2016. JMB: Jurnal Manajemen dan Bisnis, 6(1).

[12] Yohana, N., Rasyid, A., Lubis, E. E., \& Rimayanti, N. (2019). Communication of Community Participation in Implementation of Policy in Child-Friendly Regency (Kla) in Siak District. International Journal of Research in Social Sciences, 33(1), 2307-227X. 